\title{
Diagnostic value of measurement of serum type I procollagen carboxy terminal peptides in patients with scirrhous carcinoma of the stomach
}

\author{
K Kohda, N Ito, M Ohwada, K Morita, N Watanabe, Y Kohgo, Y Mogi, Y Niitsu
}

\begin{abstract}
We have evaluated the radioimmunoassay for type I procollagen carboxy terminal peptide (type I C-peptide), which is liberated from type I procollagen during its conversion to collagen, in the serodiagnosis of scirrhous carcinoma of the stomach. The mean (SD) serum concentration of type I C-peptide in 39 normal subjects was $41.7(19.7) \mathrm{ng} / \mathrm{ml}$. The mean serum values and the positive ratio of type I C-peptide in 11 patients with stages II and III scirrhous carcinoma of the stomach were $91.2(41.9)$ $\mathrm{ng} / \mathrm{ml}$ and $54.5 \%$, respectively. In 10 patients with other types of gastric carcinoma, the mean type I C-peptide values were not significantly different from the normal value. Serum type I C-peptide values reflected the clinical course of scirrhous gastric carcinoma in five patients who underwent either operation or chemotherapy. The measurement of serum type I C-peptide concentrations could provide a useful way of diagnosing and monitoring scirrhous carcinoma of the stomach.
\end{abstract}

Scirrhous carcinoma of the stomach is characterised by proliferation of interstitial connective tissue - that is, deposition of collagen and sparse infiltration of cancer cells in the interstitial tissue. Because of this, radiological or gastroscopic examination of the gastric mucosa provide very little, if any, diagnostic information until the cancer has reached an advanced stage.

Collagen is first synthesised in the form of the precursor, procollagen, then, under the extracellular action of the enzyme procollagen peptidase, the amino and carboxy terminal peptides of the procollagen are specifically cleaved, resulting in the formation of an insoluble collagen protein. ${ }^{1}$ The procollagen peptides are soluble, however, and after release from the collagen remain in the blood stream for some time. ${ }^{2-4} \mathrm{We}$ have established a radioimmunoassay for the measurement of type I procollagen carboxy terminal peptide (type I C-peptide), and have previously reported that the serum concentrations of this peptide are raised in patients with hepatic fibrosis. ${ }^{5}$

In this study, the importance of type I $\mathrm{C}$-peptide concentrations in the serodiagnosis of scirrhous carcinoma of the stomach was investigated.

\section{Methods}

PURIFICATION OF TYPE I PROCOLLAGEN IMR 90 cells (normal human lung fibroblast) were grown in culture flasks ( $\mathrm{T} 75, \mathrm{~T}$ 150; Corning) at $37^{\circ} \mathrm{C}$ in Dulbecco's modified Eagle's medium (DMEM, Grand Island Biological) with $10 \%$ fetal calf serum (FCS). ${ }^{6}$ After the cells reached their early confluent state, they were cultured for another 24 hours in serum free DMEM containing $75 \mu \mathrm{g} / \mathrm{ml}$ of ascorbate and $4 \mu \mathrm{Ci} / \mathrm{ml}$ of L-[2,3] ${ }^{3} \mathrm{H}$-prolin (New England Nuclear). The serum free medium (approximately 1 litre) was then collected. Various protease inhibitors ${ }^{6}$ were added as previously reported. ${ }^{5}$ The pellet precipitated by $176 \mathrm{mg} / \mathrm{ml}$ of ammonium sulphate was then dissolved in $20 \mathrm{ml}$ of ice cold $0.1 \mathrm{~mol} / 1$ Tris- $\mathrm{HCl}$ buffer containing $0.4 \mathrm{~mol} / 1 \mathrm{NaCl}(\mathrm{pH}=7.5)$ and centrifuged at $30000 \mathrm{~g}$ for 30 minutes. The supernatant was dialysed overnight at $4^{\circ} \mathrm{C}$ against a $0.1 \mathrm{~mol} / 1 \mathrm{Tris}-\mathrm{HCl}$ buffer $(\mathrm{pH}=7 \cdot 8)$ containing $2 \mathrm{~mol} / \mathrm{l}$ urea, $2.5 \mathrm{mmol} / \mathrm{l}$ EDTA (starting buffer A) before its application to a DEAE Sephacel column $\left(1.6 \times 10 \mathrm{~cm}^{2}\right)$ which had been equilibrated with the starting buffer $A$.

Chromatography was carried out with a linear salt gradient prepared with $150 \mathrm{ml}$ of the starting buffer $A$ and equal amounts of the same buffer containing $0.2 \mathrm{~mol} / 1 \mathrm{NaCl}$. The highest peak of the radioactivity was collected as type I procollagen. $^{5}$

\section{PREPARATION OF TYPE I C-PEPTIDE}

A solution of $10 \mathrm{mg}$ of type I procollagen in 6.0 $\mathrm{ml}$ of $0.05 \mathrm{~mol} / \mathrm{l}$ Tris- $\mathrm{HCl}$ buffer $(\mathrm{pH}=7.5)$ containing $0.4 \mathrm{~mol} / 1 \mathrm{NaCl}$ and $0.01 \mathrm{~mol} / 1 \mathrm{CaCl}_{2}$ was incubated with $300 \mu \mathrm{g}$ of high grade bacterial collagenase (Advance Biofacture) for 20 hours at $4^{\circ} \mathrm{C}$. The incubation was ended by adding $0.25 \mathrm{~mol} / 1 \mathrm{EDTA}$ in an amount one tenth the volume of the sample.

The digested peptides were fractionated by gel permeation in an $8 \%$ agarose column (Bio Gel A-1.5 m, 200-400 mesh, Bio Rad $\left.1.5 \times 90 \mathrm{~cm}^{2}\right)$ in $0.1 \mathrm{~mol} / 1$ Tris- $\mathrm{HCl}$ buffer $(\mathrm{pH}=7 \cdot 5)$ containing $0.4 \mathrm{~mol} / 1 \mathrm{NaCl}$ with a flow rate of $3.8 \mathrm{ml} /$ hour.

The first peak of three radioactive peaks recovered was concentrated and dialysed against $0.025 \mathrm{~mol} / \mathrm{l}$ Tris- $\mathrm{HCl}$ buffer $(\mathrm{pH}=8.5$, starting buffer B).

The peptides were then chromatographed on a DEAE Sephacel column $\left(1.6 \times 10 \mathrm{~cm}^{2}\right)$ with a linear gradient prepared with $100 \mathrm{ml}$ of starting buffer $B$ and $100 \mathrm{ml}$ of the same buffer containing $0.4 \mathrm{~mol} / 1 \mathrm{NaCl}$. The radioactivity of each fraction was measured in a liquid scintillation counter and the peaks of highest radioactive were collected.

The partially purified type I C-peptides $(0.7 \mathrm{mg} / 3 \mathrm{ml})$ from the DEAE Sephacel column

Accepted for publication 20 August 1990 
were first dialysed against PBS containing $5 \mathrm{mmol} / \mathrm{l}$ EDTA and then applied to the immunoabsorbent column using anti-type I procollagen antibody $\left(1.5 \times 5 \mathrm{~cm}^{2}\right)$ as previously reported. After washing the column thoroughly with phosphate buffered saline (PBS), the fractions containing high radioactivity were eluted with $3 \mathrm{~mol} / \mathrm{l}$ potassium thiocyonate (KSCN) in $\mathrm{PBS}$, and were immediately dialysed in $\mathrm{PBS}$ at $4^{\circ} \mathrm{C}$ and frozen.

RADIOIMMUNOASSAY FOR TYPE I C-PEPTIDE

A double antibody method was used for radioimmunoassay of type I C-peptide as described previously. ${ }^{5}$

The specific activity of the type I C-peptide labelled with ${ }^{125} \mathrm{I}-\mathrm{Na}$ was $14 \mu \mathrm{Ci} / \mu \mathrm{g}$. The antiserum was diluted in steps with a dilution buffer which comprised PBS, $0.25 \%$ benzene sulphonic acid (BSA), $10 \mathrm{mmol} / \mathrm{l}$ EDTA, and $0.03 \%$ Triton $\mathrm{X}-100$. Each $0 \cdot 1 \mathrm{ml}$ portion of the diluted antiserum was then mixed with $1.6 \mathrm{ng}$ (28000 counts/minute) of ${ }^{125}$ I-labelled type I C-peptide, $0.1 \mathrm{ml}$ of $5 \%$ normal rabbit serum, and $0.2 \mathrm{ml}$ of the dilution buffer, and then incubated for 48 hours at $4^{\circ} \mathrm{C}$. The solution was then mixed with $0 \cdot 1 \mathrm{ml}$ of $1: 4$ anti-rabbit IgG goat serum (Miles Co) and incubated for an additional 24 hours at $4^{\circ} \mathrm{C}$. The immunoprecipitate was centrifuged at $4500 \mathrm{~g}$ for 15 minutes, and the radioactivity of the pellet was counted in an autogammacounter. Using the diluted antiserum, an inhibition assay was performed with the same procedure as that used for titration of the antiserum, except for the substitution of $0.1 \mathrm{ml}$ of dilution buffer with $0 \cdot 1 \mathrm{ml}$ of a non-labelled antigen or sample serum. Human sera were routinely diluted $1: 4$ in a standard buffer before use.

\section{MEASUREMENT OF SERUM CONCENTRATIONS OF CARCINOEMBRYONIC ANTIGEN AND CARBOHYDRATE ANTIGEN 19-9}

Serum carcinoembryonic antigen (CEA) concentrations were determined by the sandwich method, using CEA RIA kits (Dainabot Co) and serum carbohydrate antigen 19-9 (CA19-9) values were determined similarly, using CA19-9 RIA kits (Centocor Co). The cut off values for CEA and CA19-9 were $2.5 \mathrm{ng} / \mathrm{ml}$ and $37 \mathrm{U} / \mathrm{ml}$, respectively.

\section{SUBJECTS}

Serum values of type I C-peptide were determined in blood samples collected from 39 healthy subjects, two patients with Borrmann type 1 gastric cancer, two patients with Borrmann type 2 gastric cancer, 26 patients with Borrmann type 3 gastric cancer, 20 patients with Borrmann type 4 gastric cancer, 20 patients with chronic gastritis, 15 patients with gastric ulcer, 13 patients with gastric polyps, 111 patients with chronic pancreatitis, 21 patients with colon cancer, 16 patients with oesophageal cancer, 26 patients with pancreatic cancer, and 14 patients with gall bladder cancer.

The ages ranged from 20 to 65 years (mean 43.8 years) for the healthy subjects; $28-72$ years
$(57 \cdot 4)$ for the patients with gastric cancers of Borrmann types 1,2 , and $3 ; 26$ to 73 years $(54 \cdot 3)$ for the patients with Borrmann type 4 gastric cancer; 21 to 68 years $(49 \cdot 8)$ for the patients with benign gastrointestinal disease; and 35 to 63 years $(50 \cdot 1)$ for the patients with malignant gastrointestinal disease other than gastric cancer.

\section{CLASSIFICATION AND STAGING OF GASTRIC} CANCERS

The macroscopic and histological classification and staging of gastric cancers was based on 'The General Rules for the study of Gastric Cancer in Surgery and Pathology'. The gastric cancers were examined histologically and staged on surgical or necropsy evidence. Histological examination of gastric cancers showed that two of 30 patients with gastric cancers of Borrmann types 1, 2, and 3 had papillary adenocarcinoma, four had highly differentiated and eight moderately differentiated adenocarninoma, 11 had poorly differentiated adenocarcinoma, and five had signet ring cell carcinoma. The clinical stages of gastric cancers of Borrmann types 1, 2, and 3 were: eight in stage II, two in stage III, and 20 in stage IV. Three of 20 patients with Borrmann type 4 gastric cancers were found to have moderately differentiated tubular adenocarcinoma, 22 poorly differentiated adenocarcinoma, and six signet ring cell carcinoma; and all Borrmann 4 gastric cancers were diagnosed histologically as being of the scirrhous type (two in stage II, nine in stage III, and nine in stage IV). It should be noted that none of the Borrmann types 1, 2, and 3 gastric cancers or other malignant gastrointestinal tumours were of the scirrhous type.

STATISTICAL ASSESSMENT OF DATA

The mean values were assessed for the significance of differences using Welch's test, and the differences were considered statistically significant when $\mathrm{p}<0.05$.

\section{Results}

SERUM TYPE I C-PEPTIDE VALUES IN PATIENTS WITH VARIOUS TYPES OF GASTRIC CARCINOMA The serum concentrations of type I C-peptide in patients with various types of gastric carcinoma are shown in Figure 1 and Table I. There were no stage I cancers in the group with gastric carcinoma of Borrmann type 4 and, moreover, there were inadequate numbers of patients with stage II and III disease. Therefore, focusing attention upon the presence or absence of metastases to other organs, stages II and III were grouped together and compared with stage IV. The same grouping was applied to the patients with Borrmann types 1, 2, and 3 disease. The mean (SD) serum concentration of type I C-peptide in the normal subjects was $41 \cdot 5(19 \cdot 7) \mathrm{ng} / \mathrm{ml}$ compared with $91 \cdot 2(19 \cdot 7) \mathrm{ng} / \mathrm{ml}$ for patients with Borrmann type 4 gastric carcinoma in stages II and II, representing an increase by a factor of about $2 \cdot 2$ $(\mathrm{p}<0.005)$. The mean type I C-peptide concentration in the stage IV group of Borrmann 


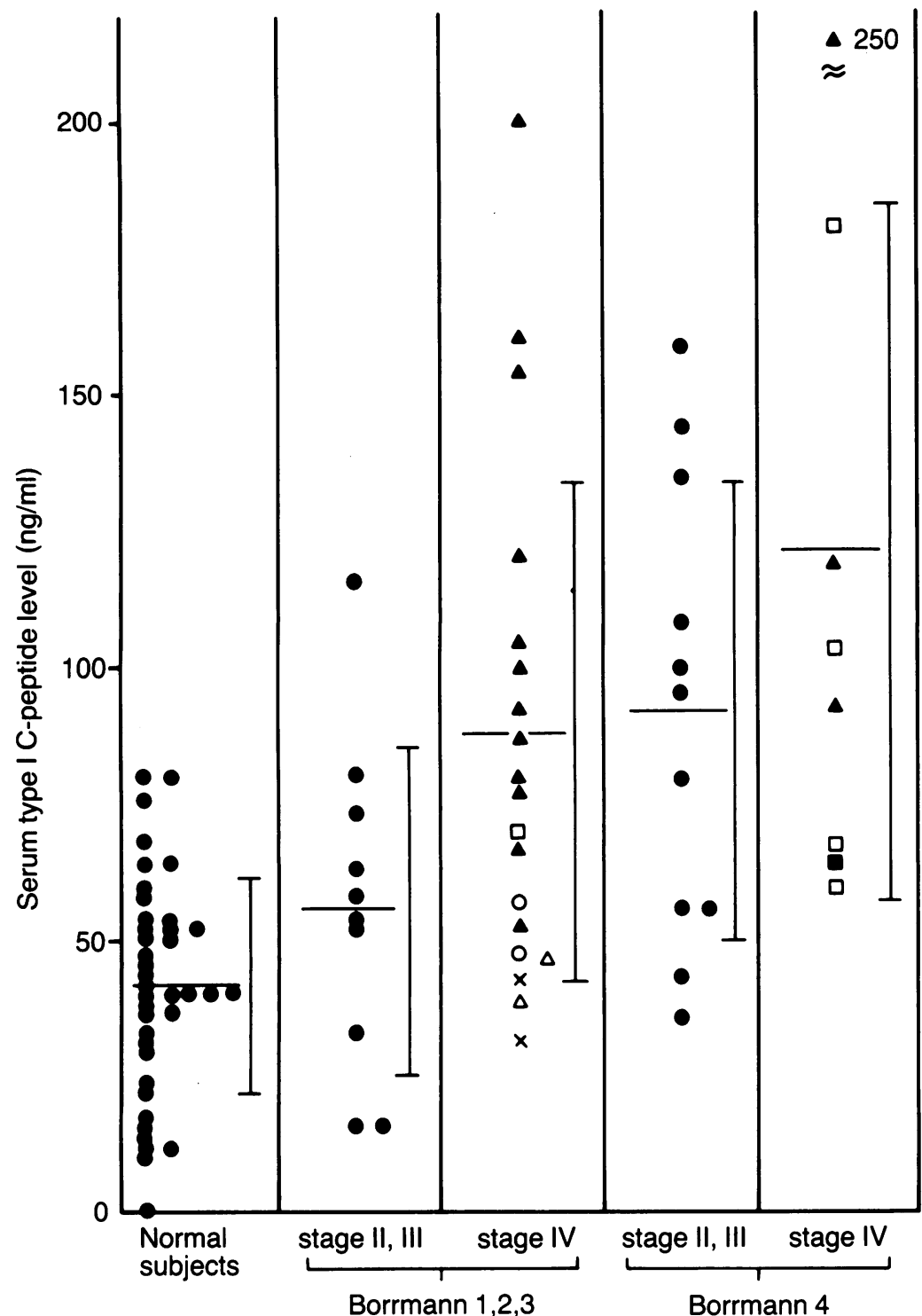

Figure 1: Serum type I procollagen carboxy terminal peptide (type I C-peptide) concentrations in normal subjects and patients with gastric carcinoma. Each value at stage IV was distinguished by using different marks that indicated the metastatic sites; the liver $(\mathbf{\Delta})$, bone $(\triangle)$, lung $(\square)$, peritoneum $(\square)$, ovary $(O)$ and pancreas $(X)$.

type 4 was $120 \cdot 5(63 \cdot 3) \mathrm{ng} / \mathrm{ml}$, which was higher than that of patients with stage II and III disease of the same Borrmann type, but not statistically significant. All Borrmann type 4 patients with liver metastases had high concentrations of type I $\mathrm{C}$-peptide. In the patients with gastric carcinoma of Borrmann type 1,2, or 3, the mean serum type I C-peptide concentrations in the stages II and III group $(55 \cdot 6(30 \cdot 1) \mathrm{ng} / \mathrm{ml})$ stayed within the normal range. In the stage IV group, however, the mean concentration was significantly higher than that of the normal group, and liver meta-

TABLE I Mean (SD) concentrations and positive ratios of serum type I procollagen carboxy terminal peptide (type I C-peptide) in normal subjects and patients with gastric carcinoma

\begin{tabular}{|c|c|c|c|c|c|c|c|}
\hline & No & $\begin{array}{l}\text { Type I } \\
C \text {-peptide } \\
(n g / m l)\end{array}$ & $\begin{array}{l}\text { Positive } \\
\text { ratio }(\%)\end{array}$ & p value & & & \\
\hline $\begin{array}{l}\text { Normal subjects } \\
\text {. }\end{array}$ & 39 & $41 \cdot 7(19 \cdot 7)$ & 0 & & & \multirow{3}{*}{$p<0.005$} & \multirow{3}{*}{$\mathrm{p}<0.005$} \\
\hline $\begin{array}{l}\text { Stage II, III } \\
\text { Stage IV }\end{array}$ & $\begin{array}{l}10 \\
20\end{array}$ & $\begin{array}{l}55 \cdot 6(30 \cdot 1) \\
87 \cdot 8(45 \cdot 4)\end{array}$ & $\begin{array}{l}10 \cdot 0 \\
45 \cdot 0\end{array}$ & $p<0.05$ & $p<0.001$ & & \\
\hline $\begin{array}{l}\text { Borrmann type 4: } \\
\text { Stage II, III } \\
\text { Stage IV }\end{array}$ & $\begin{array}{r}11 \\
9\end{array}$ & $\begin{array}{r}91 \cdot 2(41 \cdot 9) \\
120 \cdot 5(63 \cdot 3)\end{array}$ & $\begin{array}{l}54 \cdot 5 \\
66 \cdot 7\end{array}$ & \} $\mathrm{NS}$ & & & \\
\hline
\end{tabular}

TABLE II Mean $(S D)$ concentrations and positive ratios of serum type I procollagen carboxy terminal peptide (type I $C$-peptide) in patients with benign digestive diseases

\begin{tabular}{llll}
\hline & No & $\begin{array}{l}\text { Type I C-peptide } \\
(\mathrm{ng} / \mathrm{ml})\end{array}$ & $\begin{array}{l}\text { Positive } \\
\text { ratio(\%) }\end{array}$ \\
\hline Chronic gastritis & 10 & $40 \cdot 9(26 \cdot 5)$ & 0 \\
Gastric ulcer & 15 & $40 \cdot 1(11 \cdot 8)$ & 0 \\
Gastric polyp & 13 & $51 \cdot 1(15 \cdot 9)$ & 0 \\
Chronic pancreatitis & 11 & $43 \cdot 3(9 \cdot 3)$ & 0
\end{tabular}

stases were again associated with high concentrations. When the cut off level was set at the mean $+2 \mathrm{SD}$ of the normal value - that is $81 \cdot 1 \mathrm{ng} / \mathrm{ml}$ the positive ratio was $54.5 \%$ for the group with stages II or III and $66 \cdot 7 \%$ for the group with stage IV of Borrmann type 4 gastric carcinoma, and $66.7 \%$ of the positive patients in the stage IV group had liver metastases. Among the patients with gastric carcinoma of Borrmann types 1,2 , or 3 , the positive ratio for the the stage II and III group was only $10.0 \%$, whereas in the stage IV group the positive ratio was $45.0 \%$ and all of those positive had liver metastases. Although the data are not shown, there were no significant differences in serum type I C-peptide concentrations in relation to age or morphological type in any of the groups.

SERUM TYPE I C-PEPTIDE CONCENTRATIONS IN NON-MALIGNANT DISORDERS OF THE DIGESTIVE ORGANS

Table II shows the serum type I C-peptide concentrations in patients with various nonmalignant diseases of the digestive organs. The mean (SD) values $-40.9(26.5) \mathrm{ng} / \mathrm{ml}$ for chronic gastritis, $40.1(11.8) \mathrm{ng} / \mathrm{ml}$ for gastric ulcers, $51 \cdot 1(15.9) \mathrm{ng} / \mathrm{ml}$ for gastric polyps, and 43.4 (9.3) $\mathrm{ng} / \mathrm{ml}$ for chronic pancreatitis - were all within the normal range. In the chronic gastritis group, including two patients with intestinal dysplasia, and the gastric polyp group, including three with adenomatous polyps, the type I C-peptide concentrations were all within the normal range.

SERUM TYPE I C-PEPTIDE CONCENTRATIONS FOR OTHER MALIGNANT TUMOURS OF THE DIGESTIVE ORGANS

Mean values and positive ratios for serum type I $\mathrm{C}$-peptide concentrations in patients with various other malignant tumours of the digestive organs are shown in Table III. Because the mean serum type I C-peptide concentrations in all the groups without evidence of liver metastases were not raised, the positive ratio was also $0 \%$ for all these groups. In all the groups with liver metastases, however, the mean values were increased and there were high positive ratios ranging from $45 \cdot 1 \%$ to $69 \cdot 2 \%$, although these increases were not significant when compared with those in the groups with no detectable liver metastases.

POSITIVE RATIOS OF SERUM CEA AND CA 19-9 IN BORRMANN TYPE 4 GASTRIC CARCINOMA The positive ratios of serum CEA and CA 19-9 for patients with Borrmann type 4 gastric car- 

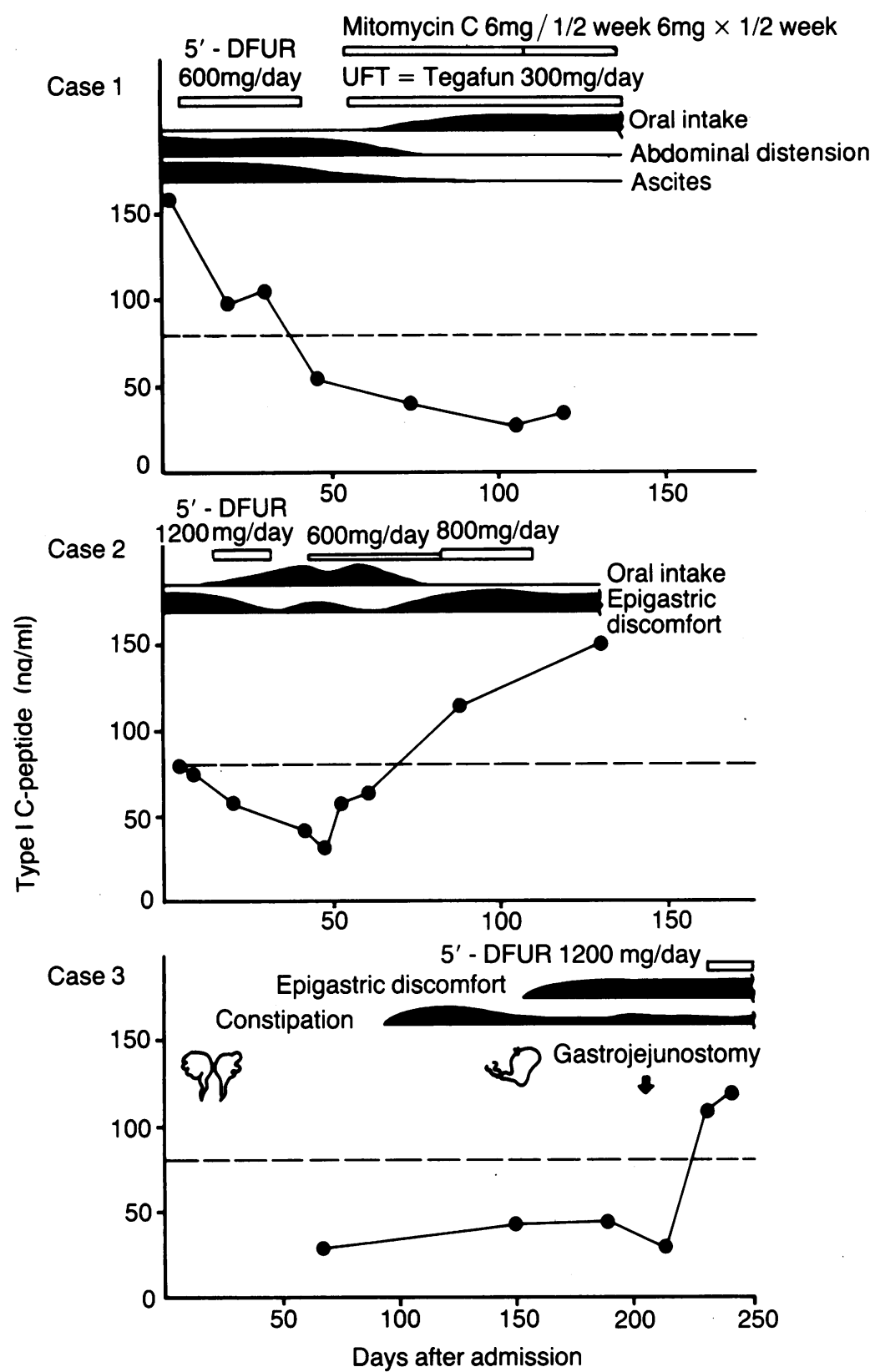

Figure 2: Changes in type I procollagen carboxy terminal peptide (type I C-peptide) concentrations in patients with scirrhous carcinoma of the stomach during chemotherapy. The broken lines represent the cut off level of the normal value $($ mean $(+S D), 41 \cdot 7(+39 \cdot 4) \mathrm{ng} / \mathrm{ml})$. $5^{\prime}-D F U R=5^{\prime}$-deoxy-fluorouridine; $M M C=$ mitomycin; $U F T=$ tegafur.

cinoma were $28 \cdot 7 \%$ and $24 \cdot 5 \%$ respectively for the stage II-III group and $41 \cdot 0 \%$ and $38.6 \%$ respectively for the stage IV group.

CHANGES IN SERUM TYPE I C-PEPTIDE CONCENTRATIONS DURING THE CLINICAL COURSE OF SCIRRHOUS GASTRIC CARCINOMA

Figures 2 and 3 show the changes in serum type I C-peptide concentrations during the clinical courses of scirrhous gastric carcinoma in three patients with inoperable disease treated with chemotherapy and two patients who had surgical resection.

Patient 1

This man, aged 72 years, had scirrhous gastric carcinoma (poorly differentiated adenocarcinoma) with accompanying peritonitis car- cinomatosa and Schnitzler's metastasis. After hospital admission, chemotherapy with a mixture of 5 '-deoxy-fluorouridine (5'-DFUR), mitomycin $\mathrm{C}$, and tegafur was started and resulted in an improvement in subjective symptoms and resolution of ascites. The patient's serum type I C-peptide concentration at the time of admission was high - $158 \mathrm{ng} / \mathrm{ml}$ - but decreased sharply during the course of therapy, and on day 120 returned to a normal concentration of $35 \mathrm{ng} / \mathrm{ml}$.

\section{Patient 2}

This man, aged 57 years, had scirrhous carcinoma (signet cell ring carcinoma) which extended from the fundus to the body of the stomach, but clinical examination showed no distant metastases. Chemotherapy with 5'-DFUR was accompanied by a gradual improvement in subjective symptoms and on day 35 gastric radiography showed improvement of stomach wall distensibility in the fundus. The patient's serum type I C-peptide concentration, which was $78 \mathrm{ng} / \mathrm{ml}$ before therapy, gradually fell, and at the same time there was an improvement in clinical findings. On day 33 it had dropped to $32 \mathrm{ng} / \mathrm{ml}$. This patient subsequently developed resistance to chemotherapy, however, and from about day 45 his condition again deteriorated. This exacerbation was accompanied by a further increase in type I C-peptide concentrations.

\section{Patient 3}

This 73 year old woman was believed retrospectively to have been in the invasive phase of scirrhous gastric carcinoma when admitted to hospital. Her main complaint at this time was right abdominal pain, and drip intravenous pyelography showed bilateral hydronephrosis. From day 100 after admission severe coprostasis developed and colonoscopic examination showed rectal stenosis. Thereafter, she suffered noticeable sensation of upper abdominal distention and gastric radiography and gastroscopy showed pyloric stenosis, huge rugae, and other findings characteristic of scirrhous carcinoma. On day 205 a gastrojejunal anastomosis was performed, and open biopsy specimen findings indicated scirrhous gastric carcinoma complicated by secondary retroperitoneal fibrosis. Her serum type I C-peptide concentration during the initial period after hospital admission was normal $(30.4 \mathrm{ng} / \mathrm{ml})$ but by day 240 , when she had advancing gastric scirrhous sclerotisation, it had risen to the high value of $120 \mathrm{ng} / \mathrm{ml}$.

\section{Patient 4}

Giant rugous scirrhous carcinoma of the body of the stomach in an 86 year old woman was treated by total gastrectomy, which showed that the lesions were at stage III (Pø, Hø, $\mathrm{n}_{2}(+)$, se), the morphological type being signet ring cell carcinoma. The serum type I C-peptide concentration immediately before surgery was $250 \mathrm{ng} / \mathrm{ml}$, and fell to $80 \mathrm{ng} / \mathrm{ml}$ on day 10 afterwards. Thereafter, chemotherapy was begun with 


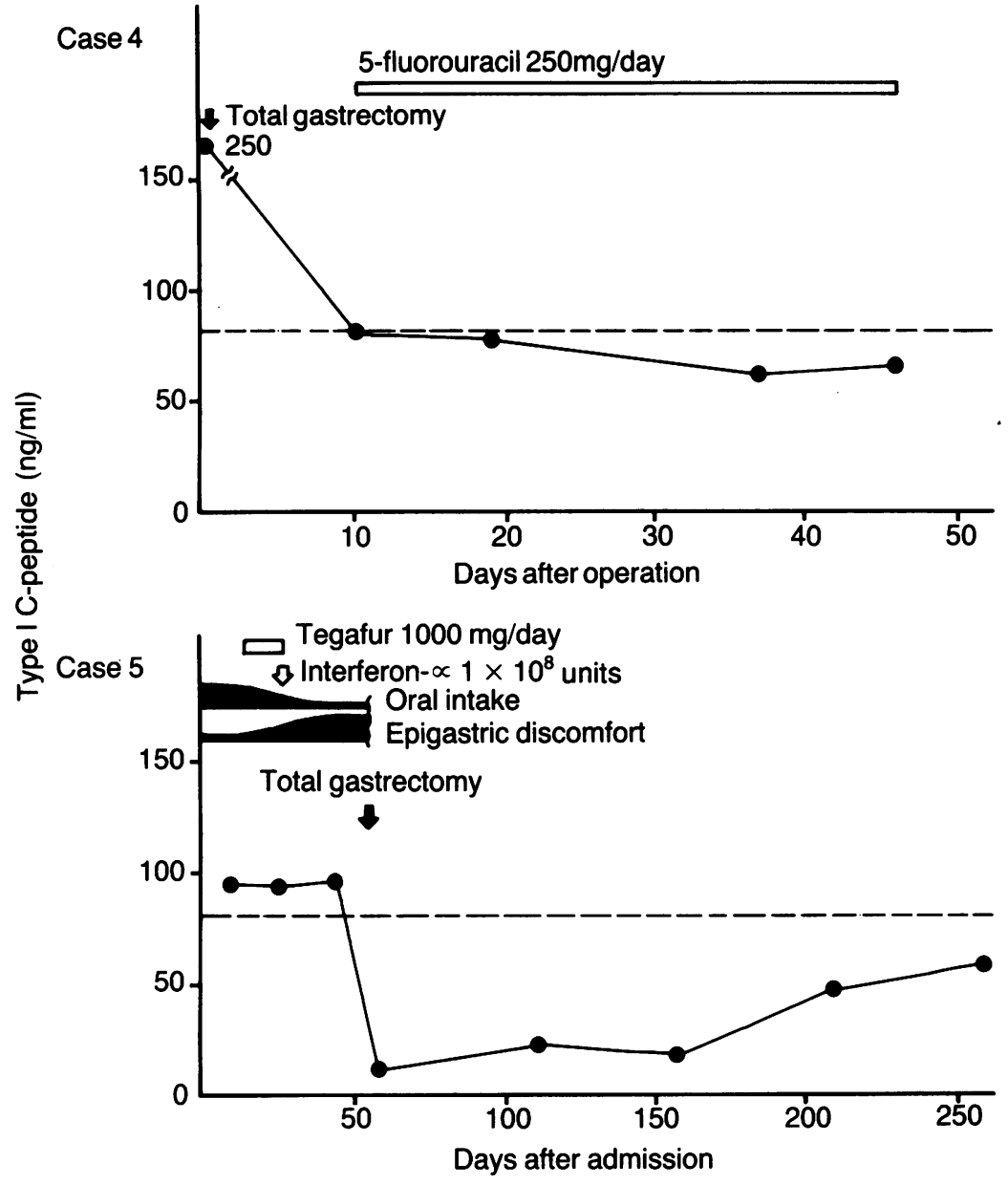

Figure 3: Changes in type I procollagen carboxy terminal peptide (type I C-peptide) concentrations in patients with scirrhous carcinoma of the stomach undergoing surgery. The broken lines represent the cut off level of the normal value (mean $(+2 S D), 41 \cdot 7$ $(+39 \cdot 4) n g / m l)$. values were sustained until surgery, but one week after operation the concentration had dropped to a normal value of $10.2 \mathrm{ng} / \mathrm{ml}$. The patient's postoperative course was initially satisfactory, but the lesions recurred within seven months of surgery, at which time an abdominal tumour mass became palpable. At the same time her type I C-peptide concentration rose to $58 \cdot 8 \mathrm{ng} / \mathrm{ml}$.

\section{Discussion}

The scirrhous type accounts for about 5 to $15 \%$ of all cases of gastric carcinoma, and early detection of this type is particularly difficult. About 50 to $70 \%$ of patients are in stage IV at the time of diagnosis and their prognosis is, therefore, extremely poor. The five year survival rate ranges from 0 to $20 \%$ and no appropriate diagnostic techniques are presently available. Furthermore, monitoring therapeutic effects is difficult since objective assessment of scirrhous carcinoma lesions, unlike that of tumourous or ulcerative gastric carcinomas, is difficult. Although biochemical tumour markers such as CEA, CA 19-9, and basic fetoprotein have been used for monitoring they are currently by no means fully satisfactory with regard to either sensitivity or specificity. Therefore, the development of a reliable quantitative marker for this purpose would be desirable.

Scirrhous gastric carcinoma is characterised by appreciable proliferation of collagen in the submucosal layer, and the total content of collagen in the stomach wall of scirrhous gastric carcinoma patients is two to four times greater than normal. Cumulative evidence indicates that extracellular matrix components, including collagen, provide tumour cells with some essential location in which they undergo proliferation, differentiation, or progression..$^{8-10}$ With immunohistochemical staining using antibodies to type I procollagen, we have previously shown that this excess collagen is produced by the scirrhous gastric carcinoma cells themselves. ${ }^{5}$

Furthermore, our preliminary investigation

\section{Patient 5}

This patient was aged 52 years. Scirrhous carcinoma was localised in the body of the stomach and no distant metastasis was detected by routine clinical examinations. After admission to hospital she was treated with tegafur and recombinant interferon- $\alpha$, but as this was ineffective, total gastrectomy was performed. The lesions were stage II (Pø, Hø, $\mathrm{n}_{1}(+)$, ss $\left.\gamma \mathbf{x}\right)$, the morphological type being signet ring cell carcinoma. Her serum type I C-peptide concentration at the time of admission was $95 \mathrm{ng} / \mathrm{ml}$. High

TABLE III Mean (SD) concentrations and positive ratios of serum type I procollagen carboxy terminal peptide (type I C-peptide) in patients with other malignant diseases of digestive organs

\begin{tabular}{|c|c|c|c|c|c|}
\hline & $\begin{array}{l}\text { Liver } \\
\text { metastasis }\end{array}$ & No & $\begin{array}{l}\text { Type I C-peptide } \\
(\text { ng/ml })\end{array}$ & $\begin{array}{l}\text { Positive } \\
\text { ratio(\%) }\end{array}$ & p value \\
\hline Colon cancer & $\bar{t}$ & $\begin{array}{r}13 \\
8\end{array}$ & $\begin{array}{l}28 \cdot 2(18 \cdot 8) \\
71 \cdot 5(34 \cdot 8)\end{array}$ & $\begin{array}{c}0 \\
45 \cdot 1\end{array}$ & \} $\mathrm{p}<0.05$ \\
\hline Oesophageal cancer & $\overline{+}$ & $\begin{array}{r}10 \\
6\end{array}$ & $\begin{array}{l}30 \cdot 2(21 \cdot 0) \\
85 \cdot 0(33 \cdot 9)\end{array}$ & $\begin{array}{c}0 \\
54 \cdot 6\end{array}$ & $p<0.001$ \\
\hline Pancreatic cancer & $\overline{+}$ & $\begin{array}{l}16 \\
10\end{array}$ & $\begin{array}{c}30 \cdot 2(7 \cdot 4) \\
109 \cdot 2(27 \cdot 2)\end{array}$ & $\begin{array}{c}0 \\
56 \cdot 6\end{array}$ & $p<0.005$ \\
\hline Gall bladder cancer & $\overline{-}$ & $\begin{array}{l}6 \\
8\end{array}$ & $\begin{array}{l}56 \cdot 8(18 \cdot 2) \\
93 \cdot 8(23 \cdot 2)\end{array}$ & $\begin{array}{l}0 \\
69 \cdot 2\end{array}$ & \}$p<0.01$ \\
\hline
\end{tabular}

also showed that scirrhous tumour cells secrete a substantial amount of tumour growth factor $\beta$, which stimulates fibroblasts to produce procollagen. In the synthesis of collagen, the amino and carboxyl terminal peptides of procollagen are released by the action of procollagen peptidase, and collagen itself is deposited in the extracellular matrix. In this process, a portion of the two terminal peptides is released into the bloodstream..$^{2-4}$ Recently, concentrations of these two procollagen peptides have been reported to be raised in diseases such as alcoholic liver fibrosis and chronic hepatitis." Serum aminoterminal peptide of type III collagen, however, is increased not only in patients with organ fibrosis but also in those with inflammation, ${ }^{12}$ and is therefore of doubtful value as an index of fibrosis. On the other hand, we have previously established a radioimmunossay technique for type I C-peptide and reported its clinical value in the diagnosis of hepatic fibrosis. ${ }^{5}$ Accordingly, in this study, we investigated the importance of serum type I C-peptide concentration as a marker of scirrhous carcinoma of the stomach. 
Firstly, serum type IC-peptide concentrations in non-scirrhous gastric carcinoma (Borrmann types 1,2 , and 3 ) were compared with those observed in patients with scirrhous carcinoma (Borrmann type 4). In the group without metastatic spread to other organs (stages II and III), those with Borrmann type 4 gastric carcinoma were found to have an average serum type I C-peptide concentration that was about 2.2 times that of the normal group, with the positive ratio of $54.5 \%$. This increase was signifcant at the level of $p<0.05$. In contrast, patients with gastric carcinoma of Borrmann types 1, 2, and 3 at stages II and III, showed no significant difference from the normal group with regard to serum type I C-peptide concentrations, and only one of these patients had a positive ratio. The simultaneously determined positive ratios for CEA and CA $19-9$ were $28 \cdot 7 \%$ and $24.5 \%$ respectively among the Borrmann type 4 gastric carcinoma patients. Thus, the type I C-peptide assays elicited a higher positive ratio than these two markers. At the present time, when there is no tumour marker specific for gastric carcinoma available for clinical diagnostic applications, the use of type I C-peptide as a tumour marker for scirrhous carcinoma of the stomach could probably be of considerable clinical value.

On the other hand, in the group with more advanced disease characterised by metastatic spread to other organs (stage IV), serum type I C-peptide concentrations tended to increase in gastric carcinoma of Borrmann types 1, 2, and 3 as well as Borrmann type 4 . We considered that this reflected the so called tumour burden. With regard to the particularly high values found in patients with liver metastases, however, we presume that, as for other tumour markers, when the metastatic site lies in an environment particularly exposed to blood flow, such as the liver, these peptides are more readily released into the blood stream.

At the same time, this finding suggested that collagen is produced not only in scirrhous but in non-scirrhous types of gastric carcinoma, and that the differences in this respect are merely quantitative. Furthermore, increases in serum type I C-peptide concentrations have been documented in patients with liver metastases from colonic, oesophageal, pancreatic, and choledochal carcinoma, where almost no fibrosis of the primary lesions is observed, suggesting that collagen may also be produced in these malignant tumours. This view is also consistent with recent findings that cancer cells themselves produce collagen. ${ }^{13-15}$

Serum type I C-peptide concentrations remained in the normal range in patients with various non-malignant disorders of the digestive organs. When we consider, however, the above mentioned fact that positive cases occurred even among patients with gastric carcinoma of Borrmann types 1,2, and 3; that high concentrations occurred in patients with liver metastases from other types of malignant tumours, and that increased concentrations reflecting the degree of hepatic fibrosis and other disorders not included in the present study also occur, ${ }^{5}$ the matter of specificity still remains in question.
We therefore tried to determine whether assay of serum type I C-peptide is useful for monitoring the effects of treatment. In patient 1 , a fall in the serum type I C-peptide concentration had already been observed while gastric radiography and other investigations still indicated no response to therapy: subsequently improvement of subjective symptoms was seen. In patient 2 , serum type I C-peptide concentrations were also a good reflection of clinical remission and exacerbation during a course of chemotherapy. Considered retrospectively, patient 3 was presumably in the invasive stage of scirrhous gastric carcinoma at the time of hospital admission. At this point, the serum type I C-peptide concentration was within the normal range, but then rose shadowing the course of progressive sclerotisation.

Patients 4 and 5 were in stages III and II respectively, with no observed metastatic spread to other organs, and in both serum type I C-peptide concentrations showed a precipitous fall after total resection of the tumours; in patient 5, serum type I C-peptide concentrations increased again with the recurrence of lesions. These findings indicate that measurement of serum type I C-peptide is also an effective means of observing the postoperative course and, moreover, that increased serum type I C-peptide originates in the scirrhous gastric carcinoma tissue itself.

In summary, the above results indicate that the measurement of serum type I C-peptide provides a clinically applicable index for the monitoring of chemotherapeutic and surgical effects in patients with scirrhous carcinoma of the stomach.

1 Bornstein P, Traub W. The chemistry and biology of collagen. In: Neuurath $\mathrm{H}$, Hill RL, eds. The proteins IV. New York, Academic Press, 1979: 411-632.

2 Taubman MB, Golderg B, Sherr CJ. Radioimmunoassay for human procollagen. Science 1974; 186: 1115-7.

3 Dehm P, Olsen BR, Prockop DJ. Antibodies to chick-tendon procollagen. Eurf Biochem 1974; 46: 107-16.

4 Murphy WH, Von der Mark K, McEneany LSG, Bornstein P. Characterization of procollagen-derived peptides unique to the precurser molecule. Biochemistry 1975; 14: 3243-50.

5 Niitsu Y, Koda K, Ito N, et al. Measurement of carboxyl terminal peptide of type I procollagen in sera of patients with viral hepatitis and liver cirrhosis. $\mathcal{f}$ Gastroenteral Hepatol 1988; 3: 159-67.

6 Uitto J, Lichtenstein JR, Bauer EA. Characterization of procollagen synthesized by matrix free cells isolated from procollagen synthesized by matrix free cells isolated

7 NagayoT,OmoriY,Okajima K, et al. Histological classification of stomach cancer. In: Japanese Research Society for Gastric Cancer, eds. The general rules for the gastric cancer study in surgery and pathology. Tokyo. Kanehara Press, 1985: 41-76. 8 Iozzo RV. Proteoglycans and intercellular tumor matrix. Curr Top Pathol 1987; 77: 207-21.

9 Labat-Robert J, Robert L. Aging of the extracellular matrix and its pathology. Exp Gerontol 1988; 23: 5-18.

10 Martinez-Herhandez A. The extracellular matrix and neoplasia. Lab Invest 1988; 58: 602-12.

11 Rohde H, Vargas L, Hahn E, Kalbfleisch H. Burguera M, Timpl R. Radioimmunoassay for type III procollagen peptide and its application to human liver disease. Eur $\mathcal{f} C l i n$ Invest 1979; 9: 451-9.

12 Bolarin DM, Savolainen ER, Kivirikko KI. Enzymes of collagen synthesis and type III procollagen amino-peptide in collagen synthesis and type III procollagen amino-peptide in
serum from Nigerians with hepatocellular carcinoma and serum from Nigerians with hepatocellular carcinoma

13 Sakakibara K, Suzuki T, Watanabe H, Nagai Y. Biosynthesis of an interstitial type of collagen by cloned human gastric carcinoma cells. Cancer Res 1982; 42: 2019-27.

14 Al-Adnani MS, Kirrane JA, McGee JO'D. Inappropriate production of collagen and prolyl hydroxylase by human breast cancer cells in vivo. Brf Cancer 1975; 31: 653-60.

15 Niitsu Y, Ito N, Kohda K, et al. Immunohistochemical identification of type I procollagen in tumor cells of scirrhous adenocarcinoma of the stomach. Br $\mathcal{F}$ Cancer 1988; 57: 79-82. 